Session XX10

\title{
K12 Engineering Education Field Experience
}

\author{
Lawrence J. Genalo, Celeste E. Ogren \\ Iowa State University
}

\begin{abstract}
Engineering faculty have offered an engineering literacy course entitled Toying With Technology ${ }^{\mathrm{SM}}$ to elementary and secondary education majors for eight years. Studies have shown that students form many of their overall career and educational attitudes as early as elementary school. Schoolteachers who have an appreciation for technology will likely convey that appreciation to their students. This will, in turn, broaden the horizons of their students regarding the opportunities they may have regarding careers in scientific and engineering disciplines. This appreciation is achieved through various engineering activities, many of which involve $\mathrm{LEGO}^{\odot}$ robotics. Providing field experiences for future teachers so they can practice teaching the engineering-based activities they've learned is crucial in their development as confident teachers.

This paper will describe one semester's extended field experience with a local $6^{\text {th }}$ grade classroom and the companion $6^{\text {th }}$ grade extended learning program (ELP) students. Hands-on, problem solving experiences are necessary in order to develop skills such as troubleshooting, innovation, and experimentation, which are national science, mathematics, and technology standards for $6^{\text {th }}$ graders. Constructivist-based methodology is employed to create goals, expected outcomes, and the logistics for the field experience. The $6^{\text {th }}$ graders use computers to follow step-by-step instructions, program their creations, and operate their systems. The students in the Toying With Technology ${ }^{\mathrm{SM}}$ course serve as classroom facilitators for the engineering activities used to attain the goals and achieve the outcomes desired. Assessment of the success of the program is through multiple measures. These include: a written feedback from the $6^{\text {th }}$ graders with answers to specific questions as well as any comments, observations and feedback by the TWT student facilitators during problem solving and design projects, interpretations of the results by the TWT class facilitator, and interviews with the collaborating in-service teachers.
\end{abstract}

\section{Introduction/Need}

"At the heart of our modern technological society lies an unacknowledged paradox. Although the United States is increasingly defined by and dependent on technology and is adopting new technologies at a breathtaking pace, its citizens are not equipped to make well-considered decisions or to think critically about technology. As a society, we are not even fully aware of, or conversant with, the technologies we use every day. In short, we are not 'technologically literate." $" 1$ 
Now more than ever, the United States needs a skilled, technologically literate workforce whose members can address problems with time-tested solutions as well as creative problem solving. Increasing the pool of workers with strong problem-solving skills requires that students have experiences in quality science and mathematics problem-solving environments. Numerous studies $^{2-7}$ have shown the need for more hands-on, project-oriented, (engineering) exercises for K-12 students. Engineering offers an effective context for these problem situations. By "engineering context" we do not mean to replace existing math and science curriculum in schools, but to enhance the curriculum by infusing engineering as a learning tool. For example, when students are learning how to multiply fractions, they could be asked to do this with paper and pencil and learn the rules of fraction multiplication by rote. Instead, with engineering context, they can be asked to design a gearbox that would propel a small robotic car up an incline. To do this several gears with differing gear ratios would be meshed and their gear ratios (fractions) would have to be multiplied to arrive at the machine's overall gear ratio. Providing teachers the training necessary to make use of such engineering contexts is crucial to the success of curricular improvement. ${ }^{8}$

The need for technologically capable K-12 teachers is well documented. ${ }^{9-13}$ There is a similarly strong demand for engineers. ${ }^{14,15}$ Taken together these projections suggest a strong need for high quality, standards-based science and mathematics learning environments for K-12 students. During congressional hearings on "Improving Math \& Science Education So That No Child Is Left Behind," the Subcommittee asked the following question of Philip M. Sadler, the director of the Science Education Department at the Harvard-Smithsonian Center for Astrophysics. Dr. Sadler has had experience in running numerous partnerships aimed at improving math and science education from the higher education perspective. "Scientists, engineers, and mathematicians are relatively new players in the world of K-12 education and their participation is often ad-hoc and unstructured. How has the work of your Center benefited from the structured, long-term inclusion of these individuals and how can we encourage more practitioners of science, mathematics and engineering to get involved in K-12 program?" Dr. Sadler responded. "I like to characterize how scientists and engineers have contributed in two ways. First, many have acted as consultants, providing expertise that requires little change in perspective from their scientific research. Second, and by far, the largest impact has come from individual scientists who have committed themselves to education. They have become educators. This has meant following the same approach they would use in delving into a new field of science. They have studied the problems hard, read the research literature in the field, gone to conferences to hear about the latest experiments and innovations, partnered with educational researchers and classroom teachers to plan and pursue programs. They insist on careful experimentation and evaluation of impact. "l6

In How People Learn, ${ }^{17}$ a publication sponsored by the Commission on Behavioral and Social Sciences and Education and the National Research Council, the authors emphasize the emergence of a new science of learning that is based in the growing body of research on human learning. The authors point out that "Overall, the new science of learning is beginning to provide knowledge to improve significantly people's abilities to become active learners who seek to understand complex subject matter and are better prepared to transfer what they have learned to new problems and settings."

Proceedings of the 2005 American Society for Engineering Education Annual Conference \& Exposition Copyright (C) 2005, American Society for Engineering Education 


\section{The Toying With Technology ${ }^{\text {SM }}$ Program}

Many existing K-12 engineering context-based educational experiences have been devised in engineering colleges, but few are aligned with national science and mathematics standards and integrated into an age-appropriate curriculum and few are geared toward systemic change through education of preservice and inservice teachers. Two web sites that list engineering context materials are NSF's http://www.nsf.gov/sbe/srs/seind00/access/chapter3 and ASEE's http://www.asee.org/K-8smet ed/default.cfm.

An example field experience, described later in this paper, is taken from the Toying With Technology ${ }^{\text {SM }}$ (TWT) Program at Iowa State. ${ }^{18-23}$ It will demonstrate how we bring engineering context to standards based K-12 science and mathematics curricula and to relate this work to teacher education. The TWT program includes teacher education courses at the undergraduate and graduate levels (offered in the summer to accommodate inservice teachers), workshops for teachers and faculty, and experiential classroom partnerships with K-12 schools. Existing engineering materials, such as those developed by Seymour Papert at MIT, ${ }^{24}$ Ellen Frye at Dartmouth, ${ }^{25}$ Martha Cyr formerly while at Tufts, ${ }^{26}$ and Richard Drushel at Case Western, ${ }^{27}$ to name just a few, are adapted for use in the TWT Program and its partner schools. Other materials that are developed are based on constructivist principles espoused by Papert. ${ }^{24}$

\section{Constructivism \& Constructionism}

The "constructivist" paradigm ${ }^{28,29}$ asserts that learning occurs through a process in which the student plays an active role in constructing the set of conceptual structures that constitute his or her own knowledge base. Some specific examples of the successful application of technology grounded in constructivist theory are evident in projects in the Carter Lawrence School (Tennessee), Clearview Elementary School (California), Ralph Bunche School (New York) and the Apple Classroom of Tomorrow (ACOT) studies. Jean Piaget ${ }^{30}$ developed a child-centered, developmental theory of learning. According to his theory, children construct knowledge about their world through their active involvement in experiences that are meaningful for them in order to provide an ideal learning environment.

Seymour Papert, who invented the LOGO language, tied constructivist classroom principles to children's robotics exercises with LEGO $^{\circledR}$ s. Papert, who worked with Piaget and continues to be a leader in this field, coined the term "constructionism" to refer to constructivist practices applied to a learning environment in which the students are constructing objects. ${ }^{31}$ Papert ${ }^{24}$ defines constructionism as "an epistemological reversion to more concrete ways of knowing." Various studies ${ }^{32-34}$ report on the efficacy of the active learner who is engaged in the construction of a project. 


\section{Field Experience}

\section{Introduction/Logistics}

Twenty-four Toying with Technology ${ }^{\text {SM }}$ students were assigned an elementary classroom where they would spend four weeks working with children and helping them complete technology based activities. The majority of the class was assigned to a $6^{\text {th }}$ grade classroom split up into two different sections; regular and ELP (Extended Learning Program). The activities that were to be completed include the basic Lego car programming (see reference 23), building and testing an egg drop creation, and if time allowed, challenge sheets which had students think creatively to build a structure and complete certain tasks. Since constructivism is being practiced in this class and its related outreach programs, the TWT students were assigned to pairs of $6^{\text {th }}$ graders to work cooperatively with, and guide them along with helpful hints or suggestions, but not give away correct solutions to the problems. This is an admittedly "facilitator rich" experience as there was one TWT students for each pair of $6^{\text {th }}$ graders. One of the main goals of this experience is for the elementary students to problem solve, and to become more familiar with technology and computer applications in the classroom. For four weeks the TWT students spent each Tuesday and Thursday for two hours (the regular TWT class meetings) with the $6^{\text {th }}$ graders facilitating exercises similar to ones they first experienced as students themselves earlier in the semester.

\section{Expected outcomes}

The $6^{\text {th }}$ graders were expected to work with their classmate and their "ISU buddy" to problem solve and find solutions to the tasks that were presented to them. They were given a desired goal and it was their job to use their groups' combined knowledge to find a way to reach the goal. For the egg drop activity, the goal was to successfully move a raw egg from the top of the table to the floor without breaking it. The materials supplied were only those found in one LEGO ${ }^{\odot}$ Mindstorms kit. The students at this point were already familiar with the basic programming of the LEGO $^{\odot}$ Mindstorms RCX since they had done the robotic car projects. They applied this knowledge and creative, team-based problem solving to complete the project. The egg drop activity has been matched to certain desired standards to be achieved. Although Iowa does not use national, or even statewide, standards, the activities in the egg drop problem are matched to national standards in Table 1 for readers' uniformity. Individual school districts in Iowa maintain their own district-wide standards. These standards vary greatly and are being reviewed at the district and state levels in light of the No Child Left Behind legislation and its impact on each district. Since the TWT program deals with many districts, it adheres to the national standards and "customizes" activities for each district. In some cases the TWT program has been unable to work with certain grade levels in certain districts because the local standards didn't fit the activities to be undertaken. An example of an egg drop design is shown in Figure 1. 
Table 1: National Standards and the Egg Drop

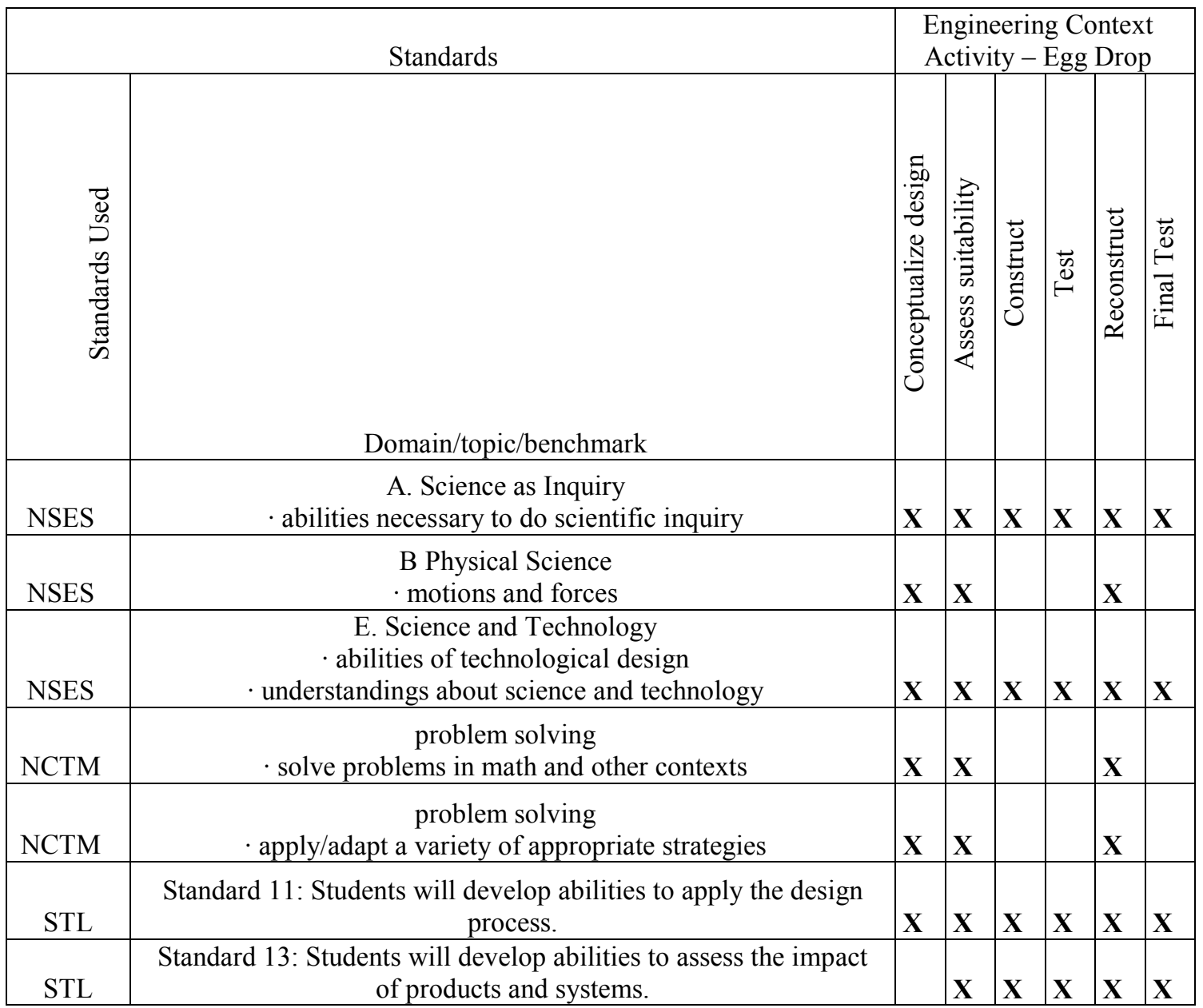

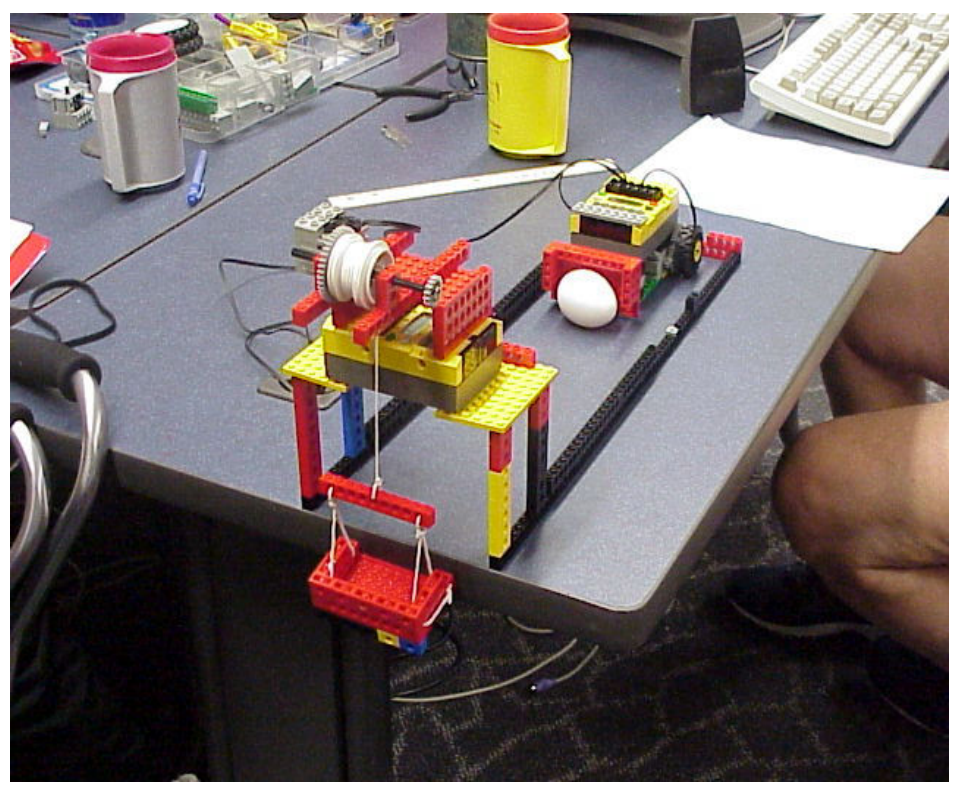

Figure 1: An Egg Drop Design

Proceedings of the 2005 American Society for Engineering Education Annual Conference \& Exposition Copyright $(\mathrm{C})$ 2005, American Society for Engineering Education 


\section{Results}

The students were successful at completing the task for the most part. Even if their egg did break, many students were eager to discuss what they thought went wrong, and how they could fix it to make it better. This was exciting to see because they were learning, even if the end result was not perfect. The results were pleasing, and it appeared that the goals were met through this experience. According to the $6^{\text {th }}$ graders feedback, the majority of the students felt that it was a worthwhile experience and they learned a lot about how to program cars to attain certain outcomes. Many of them said that their favorite part was the egg drop activity, and also that they learned new information about light sensors, bump sensors, and thresholds. When asked to state three things they learned they didn't know before, Ezra said, "I learned about thresholds, that light sensors are very helpful, and that every day complicated things are really just bigger versions of the stuff I did with the brick." They felt that their ISU buddy was helpful, and gave them suggestions when they were stuck. The TWT students also gave feedback that this was a positive learning experience for them. On a scale of 1-10 with 10 being the highest, the average rating of the classroom experience was a 9.17. Comments on the experience suggest that they felt the $6^{\text {th }}$ graders learned a lot and that the TWT students also learned a great deal. They commented that in order to teach the information to the $6^{\text {th }}$ graders, they had to know the information better then they did when working with it as students. One TWT student stated, "The whole thing was awesome because it gave us experience with using engineering in a classroom."

It was a fun and challenging experience and it was enjoyed because it gave the TWT students great practice with using engineering in a classroom, which is a goal of the TWT class as a whole. The $6^{\text {th }}$ grade classroom teacher and the ELP teacher thought this was a great experience for their students. They liked how their students were allowed time to figure things out on their own, before a TWT student would give them instruction. They both said it was a worthwhile project and they would enjoy having TWT students work with their classes again. Overall, the classroom experience was successful for the $6^{\text {th }}$ grade students and the TWT students. The student supervisor of the TWT students enjoyed watching the $6^{\text {th }}$ grade students engage in the problems that were presented, use various methods to try to accomplish their goals, and enjoy the results when their creations worked the way they wanted them to. The positive feedbacks from both groups of students showed that the goals of the program were met, and implementing technology into the classroom is an important part of an educator's curriculum in today's society.

\section{Conclusion}

Each semester the Toying With Technology ${ }^{\mathrm{SM}}$ course is offered to about 20 - 30 future K-12 teachers. The field experience described here, or one similar to it, has become a regular and important portion of the class. As mentioned earlier, providing teachers the training necessary to make use of such engineering contexts is crucial to the success of curricular improvement. ${ }^{8}$ This field experience is helping this course provide such practical training for future teachers. 


\section{Bibliography}

References

1. National Academy of Engineering (2002). Technically Speaking: Why All Americans Need to Know More About Technology, National Academy Press, Washington, DC.

2. American Association for the Advancement of Science (1993). Benchmarks for Science Literacy, Oxford University Press: New York.

3. National Research Council (1996). National Science Education Standards. National Academy Press: Washington, DC.

4. National Council of Teachers of Mathematics (2000), Principles and Standards for School Mathematics, NCTM, Washington, DC.

5. Schoenfeld, A. H. (1985). Mathematical Problem Solving. San Diego CA: Academic Press Inc.

6. Streefland L. (1991). Fractions in Realistic Mathematics Education. Dordrecht/Boston/London: Kluwer Academic Publishers.

7. Kamii, Constance (2000) Number in preschool \& Kindergarten. National Association for the Education of Young Children: New York.

8. Cannon, J.R. and Crowther, D.T., "An Autopsy of an Elementary Science Program Implementation," presented at the National Association for Research in Science Teaching, Oak Brook, IL, 1997.

9. National Commission on Mathematics and Science Teaching for the 21st Century, 2000

10. The Iowa Board of Educational Examiners and Iowa Department of Education's Basic Education Data Survey at www.nea.org and the Urban Teacher Collaborative, 2000.

11. Newberry, P., "Technology education in the U. S.: a status report," The Technology Teacher 61(1):8-12. 2001.

12. Weston, S., "Teacher Shortage-Supply and Demand," The Technology Teacher, 57(2):6-9. 1997.

13. NCES (National Center for Education Statistics), Digest of Education Statistics, 2000. On-line at http://nces.ed.gov/pubs2001/digest/dt068.html.

14. Bureau of Labor Statistics News Release 2000-2010 employment projection.

15. Kapur and Associates, Inc. Newsletter, Volume 8, Issue 2, Spring/Summer 2001.

16. "Improving Math \& Science Education So That No Child Is Left Behind." Hearing before the subcommittee on Science, House of Representatives, One Hundred Seventh Congress, First Session, ED 463 176, 2001-05-02, p15.

17. Bransford, J. D., Brown, A. L., \& Cocking, R. R. (Eds.). (1999). How People Learn: Brain, Mind, Experience and School. Washington DC: National Academy Press.

18. Genalo, L.J. and Gallagher, M., "Practicing Teachers in a Graduate Engineering Course," Proceedings of the ASEE Annual Conference, June, 2002.

19. Genalo, L.J., Gallagher, M., Golder, J. “An Engineering Linkage to K-12 Teachers,” Proceedings of the ASEE Annual Conference, June, 2001.

20. Genalo, L. J., Wright C. T., Wright K. B., "Toying with Technology in Elementary Education,” Proceedings of the Frontiers in Education Annual Conference, on CD - Session \# S4H, November, 1998.

21. Genalo, L. J., Wright C. T., Jr., Wright K. B., Collier, C. L., "Toying with Technology: Mobile Robots and High School Interns," Proceedings of the ASEE Annual Conference, on CD - Session \# 1692, June 1997.

22. Genalo, L.J., Schmidt, D., Schiltz, M., "Piaget and Engineering Education," Proceedings of the ASEE Annual Conference, June, 2004.

23. Genalo, L.J., "Engineering as Context for K-12 Science, Mathematics, and Technology Education," Proceedings of the ASEE Annual Conference, June, 2003.

24. Seymour Papert, THE CHILDREN'S MACHINE, Rethinking School in the Age of the Compute, 1993, Basic Books, New York.

25. Frye, Ellen, Engineering Problem Solving for Mathematics, Science, and Technology Education. Dartmouth Project for Teaching Engineering Problem Solving, 1996.

26. Scott McNamara, Martha Cyr, Chris Rogers, Barbara Bratzel, "LEGO Brick Sculptures and Robotics in Education," Proceedings of the ASEE Annual Conference, June, 1999.

27. Drushel, R., http://www.eecs.cwru.edu/courses/lego375/egghunt.html.

28. Duffy, T. \& Jonassen, D., Constructivism and technology of Instruction: A conversation. 1992.

29. Lane, C. \& Cassidy, S., The role of technology in the systemic reform of education and training. $E D$ Journal, 8(6), 1-22, 1994.

30. Piaget, J., The Science of Education amd the Psychology of the Child. NY: Grossman, 1970.

31. Papert, S., 'Introduction.' In I. Harel (Ed.), Constructionist learning. Boston: MIT, 1990.

Proceedings of the 2005 American Society for Engineering Education Annual Conference \& Exposition Copyright (C) 2005, American Society for Engineering Education 
32. Harel, I. And Papert, S., Constructionism:Research Reports and Essays, Blex Corp., 1991.

33. Kafai, Y. and Resnick, M., "Constructionism in Practice. Designing, Thinking, and Learning in a Digital World," Lawrence Erlbaum Associates, 1996.

34. Martin, F., "Kids Learning Engineering Science using LEGO and the Programmable Brick," in the proceedings of AERA 1996 Annual Meeting, April, 1996.

\section{LAWRENCE J. GENALO}

is Professor and Assistant Chair of the Department of Materials Science and Engineering at Iowa State University. He received a Ph. D. in Applied Mathematics with Systems Engineering emphasis in 1977, served as Chair for Freshman Programs and DELOS Divisions, and runs the Toying With Technology ${ }^{\text {SM }}$ Program at Iowa State.

\section{CELESTE E. OGREN}

is a junior in elementary education from Marcus, Iowa. She works in the Toying With Technology ${ }^{\mathrm{SM}}$ Laboratory as an undergraduate teaching/laboratory assistant. Her interests include integrating engineering and technology concepts into the elementary education curriculum and helping preservice teachers become more aware of the opportunities available to incorporate these important subject areas into their every day curriculum. 